\title{
An update on anti-Helicobacter pylori treatment in children
}

\author{
Renuka Khurana MBBS MPH${ }^{1}$, Lori Fischbach MPH PhD², Naoki Chiba MD MSc ${ }^{3}$, Sander Veldhuyzen van Zanten $\mathrm{MD}^{4}$
}

\begin{abstract}
R Khurana, L Fischbach, N Chiba, S Veldhuyzen van Zanten. An update on anti-Helicobacter pylori treatment in children. Can J Gastroenterol 2005;19(7):441-445.
\end{abstract}

\begin{abstract}
Previous consensus statements have recommended one- to two-week proton pump inhibitor (PPI)-based triple therapies with clarithromycin and either amoxicillin or metronidazole as first-line treatments for children with Helicobacter pylori infection. The objective of the present review was to summarize data from pediatric studies that have examined treatment efficacy, safety, drug resistance and reinfection rates related to anti- $H$ pylori therapies. Data from a recent metaanalysis of pediatric studies were used along with the authors' existing databases and searches of individual studies. Regimens that were identified as greater than $80 \%$ efficacious in children included a twoweek therapy with a nitroimidazole and amoxicillin in Europe; a twoweek regimen of bismuth, amoxicillin and metronidazole in developed countries (except Spain); a one- to two-week regimen of a PPI, clarithromycin and amoxicillin in Northern Europe, Asia and the Middle East; and a two-week regimen of a PPI, clarithromycin and metronidazole in Canada. Although recommended as a first-line treatment in adults, two-week treatment with a PPI, clarithromycin and amoxicillin eradicated only $68 \%$ of $\mathrm{H}$ pylori infections in North American children. Treatment efficacy was reduced in the presence of metronidazole and/or clarithromycin resistance. Further studies of anti-H pylori treatments in children in North America and developing countries are warranted.
\end{abstract}

Key Words: Children; Helicobacter pylori; Review; Treatment efficacy; Update

Telicobacter pylori infection acquired during childhood 1 causes clinical disease in only a small proportion of infected individuals (1). Nevertheless, $H$ pylori infection is a leading cause of peptic ulcer disease, and its eradication results in a long-term cure for patients (1-4). In 1999 and 2000, the Canadian Helicobacter Study Group (5) and the North American Society for Pediatric Gastroenterology and Nutrition (6) recommended proton pump inhibitor (PPI)based triple therapies with clarithromycin (C) and either amoxicillin (PPI-CA) or metronidazole (PPI-CM) for one to two weeks as first-line treatment of $H$ pylori infection in children. The North American Society for Pediatric Gastroenterology and Nutrition also recommended PPIbased triple therapy with amoxicillin and metronidazole (6). These previous guidelines were based on level I evidence

\author{
Mise à jour d'un traitement contre \\ l'Helicobacter pylori chez les enfants
}

Dans les documents consensuels passés, on recommande une trithérapie aux inhibiteurs de la pompe à protons (IPP) associée à de la clarithromycine et à de l'amoxicilline ou à du métronidazole comme traitement de première intention pour les enfants atteints d'une infection à Helicobacter pylori. La présente analyse vise à résumer les données tirées d'études pédiatriques qui portaient sur l'efficacité et l'innocuité des traitements, la résistance aux médicaments et les taux de réinfection par rapport aux traitements contre l'H pylori. Les données tirées d'une récente méta-analyse d'études pédiatriques ont été utilisées en plus des bases de données existantes de l'auteur et de recherches dans des études individuelles. Les posologies efficaces à plus de $80 \%$ chez les enfants sont un traitement de deux semaines à au nitroimidazole et à l'amoxicilline en Europe, un traitement de deux semaines au bismuth, à l'amoxicilline et au métronidazole dans les pays en voie de développement (sauf l'Espagne), un traitement de une ou deux semaines à l'IPP, à la clarithromycine et à l'amoxicilline en Europe du Nord, en Asie et au Moyen-Orient et un traitement de deux semaines à l'IPP, à la clarithromycine et au métronidazole au Canada. Bien qu'il soit recommandé comme traitement de première intention chez les adultes, un traitement de deux semaines à l'IPP, à la clarithromycine et à l'amoxicilline n'a éradiqué que $68 \%$ des infections à $H$ pylori chez les enfants nord-américains. L'efficacité du traitement diminuait en présence d'une résistance au métronidazole ou à la clarithromycine. D'autres études des traitements contre l'H pylori s'imposent chez les enfants de l'Amérique du Nord et des pays en voie de développement.

from studies in adult populations and adult recommendations because there were insufficient pediatric clinical trials $(7,8)$. The following review provides an updated summary of evidence from pediatric and adult studies regarding the efficacy, safety, drug resistance and reinfection rates of anti-H pylori therapies.

\section{METHODS}

To summarize the efficacy of anti-H pylori treatment and adverse events in children, evidence was used from the authors' recent meta-analysis of pediatric studies (unpublished data). Additionally, data were used from the authors' existing databases and Medline searches using the key words 'Helicobacter pylori' or 'Campylobacter pylori', and 'therapy' or 'treatment', 'reinfection', 'drug resistance', and 'rescue' or 'second-line therapy'.

\footnotetext{
${ }^{1}$ Community Oriented Primary Care, Parkland Health and Hospital Systems, Dallas; ${ }^{2}$ University of North Texas, School of Public Health, Fort Worth, Texas, USA; ${ }^{3}$ Surrey GI Clinic/Research, Guelph; and Division of Gastroenterology, McMaster University, Hamilton, Ontario; ${ }^{4}$ Division of Gastroenterology, Dalhousie University, Halifax, Nova Scotia

Correspondence and reprints: Dr R Khurana, Community Oriented Primary Care, Parkland Health and Hospital Systems, 4444 Hampton Road, Dallas, Texas 75232, USA. Telephone 214-266-1467, fax 214-266-1455, e-mail rkhura@parknet.pmh.org
} 


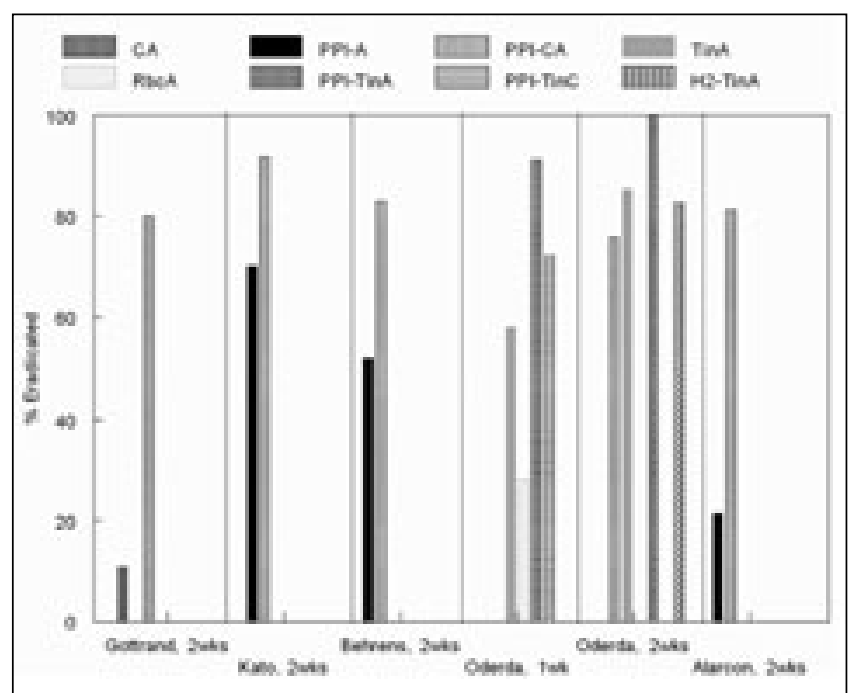

Figure 1) Efficacy of head-to-head dual versus triple therapies given for the same duration. CA Clarithromycin and amoxicillin; $\mathrm{H}_{2}$-TinA $\mathrm{H}_{2}$-receptor antagonist, tinidazole and amoxicillin; PPI-A Proton pump inhibitor and amoxicillin; PPI-CA PPI, clarithromycin and amoxicillin; PPI-TinA PPI, tinidazole and amoxicillin; PPI-TinC PPI, tinidazole and clarithromycin; RbcA Ranitidine, bismuth citrate and amoxicillin; TinA Tinidazole and amoxicillin; wk Week

\section{Efficacy}

\section{RESULTS}

The meta-analysis included 99 treatment arms and 67 studies from 25 countries across four continents (unpublished data). It provided data up to May 2004 on 23 treatment regimens used to eradicate $H$ pylori in 3175 children. The vast majority of studies were nonrandomized with fewer than 50 subjects.

Treatment efficacy varied according to the number and type of drugs used in the regimen, treatment duration, geographical location and the methods used to assess eradication after treatment. Only $5 \%$ or less of the infections were eradicated using a placebo, $\mathrm{H}_{2}$-receptor antagonist, sucralfate or omeprazole alone in five treatment arms (9-13). Dual therapy with amoxicillin and a nitroimidazole (tinidazole or metronidazole) (AN) was more efficacious in children than in adults (14). Overall, the mean eradication rate for this dual therapy was 83.9\% (365 eradicated of 435 treated) in nine treatment arms when given from 10 days to six weeks (95\% CI $80.2 \%$ to $87.2 \%)$; however, this dual therapy's efficacy was greatly reduced in Kuwait (15) and when given for only one week (10). Other dual therapies eradicated less than $80 \%$ of infections in most studies (unpublished data).

Triple therapies were more efficacious compared with dual therapies given for the same duration (Figure 1) (10,16-19). Tinidazole and amoxicillin dual therapy (TinA), which performed well when given for two weeks, tended to perform better when a PPI was added (PPI-TinA) (eradication $85 \%$ versus $100 \% ; \mathrm{P}=0.17$ ) (10). However, eradication of H pylori with PPI$\operatorname{Tin} \mathrm{A}$ was significantly better than with $\operatorname{Tin} \mathrm{A}$ when the treatment duration was one week $(P=0.004)(10)$. PPI-CA, the most commonly tested regimen, cured $58 \%$ to $100 \%$ of $\mathrm{H}$ pylori infections in 29 treatment arms with 1014 children. More than $80 \%$ of $H$ pylori infections in trials from Asia, the Middle East and European countries outside of Italy and Spain were eradicated

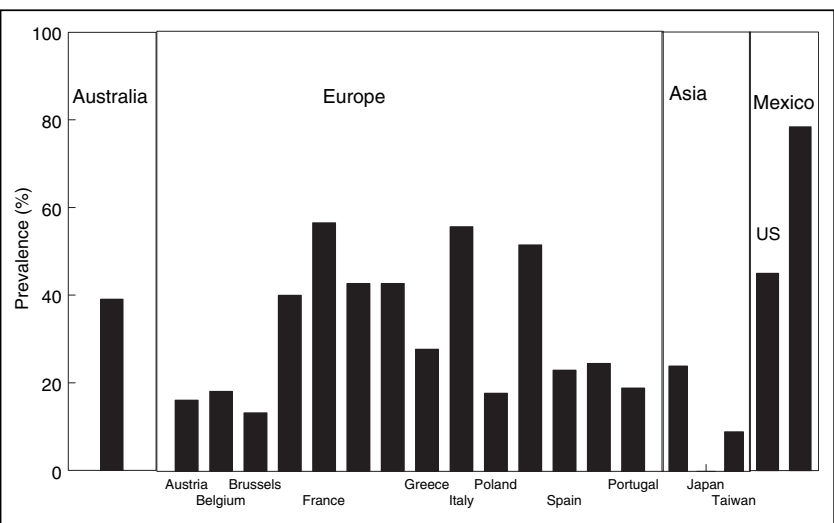

Figure 2) Prevalence of primary metronidazole resistance in children. US United States

using PPI-CA, irrespective of treatment duration. However, in the United States, only $68 \%$ of infections were eradicated using two-week PPI-CA treatments (20). Two-week therapy with a bismuth compound, amoxicillin and metronidazole (BAM), given in developed countries outside of Spain, eradicated H pylori in more than $80 \%$ of children. A PPI, macrolide and a nitroimidazole regimen (PPI-MacN) typically eradicated less than $80 \%$ of $H$ pylori infections, but in one small nonrandomized study in Canada, $93.3 \%$ erradication was achieved with two-week therapy (21). Only three quadruple-treatment regimens were tested, each for one week in a small number of children. Treatment with a nitroimidazole, amoxicillin and furazolidone, and either ranitidine or omeprazole resulted in eradication of $70 \%$ (seven of 10 ) or $80 \%$ (four of five) of infections in Brazilian children, respectively (22). Furazolidone is an inexpensive antibiotic, commonly used in South America, but not available in North America. One-week treatment with metronidazole, clarithromycin, amoxicillin and omeprazole eradicated $94 \%$ (31 of 33 ) of $H$ pylori infections in children in Hong Kong (23).

\section{Adverse events}

Only mild adverse events have been observed in $H$ pylori treatment trials in children, but the manner in which adverse events were recorded and the occurrence of adverse events varied greatly between studies (unpublished data). Adverse events were observed in $0 \%$ to $34 \%$ of subjects given a dual therapy over one to six weeks of treatment, and in $0 \%$ to $80 \%$ of subjects given a triple therapy for one to three weeks (unpublished data). In head-to-head studies, triple therapies did not result in more adverse events compared with dual therapies. In one study (16), there were more adverse events with dual therapy using clarithromycin and amoxicillin compared with PPI-CA (34\% versus 14\%; $\mathrm{P}<0.0001$ ). Although there has been some concern over the use of bismuth salts in children and its association with encephalopathy (3), bismuth levels were found to be well below toxic levels in children $(24,25)$.

\section{Drug resistance}

Resistance of $\mathrm{H}$ pylori to commonly used antibiotics is a recognized problem $(26,27)$. Marked geographical variation for primary drug resistance to $H$ pylori in children was observed (Figures 2 and 3). Primary resistance to metronidazole ranged from $13 \%$ to $57 \%$ in Europe (20,25-43), 39\% in Australia (44), 


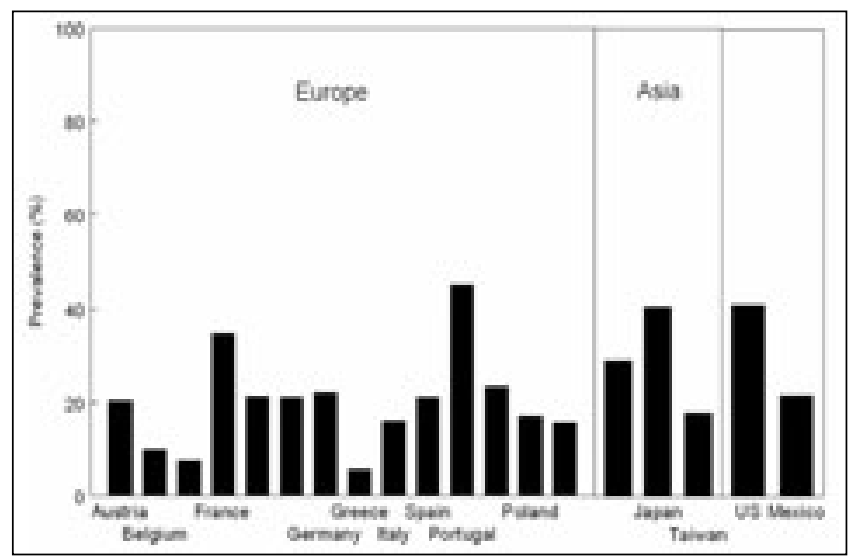

Figure 3) Prevalence of primary clarithromycin resistance in children. US United States

$0 \%$ to $24 \%$ in Japan $(45,46), 9 \%$ in Taiwan $(47)$ and $45 \%$ in the United States (48). The highest reported prevalence of primary metronidazole resistance $(78.4 \%)$ was in Mexico (49). Prevalence of secondary metronidazole resistance was $4 \%$ in Australia, 30\% in Belgium and 52\% in France $(35,42,44)$. The prevalence of primary clarithromycin resistance in children was lower than metronidazole resistance in Europe, where it ranged from $6 \%$ to $45 \%(33-43,50-55)$; in the United States, the prevalence of clarithromycin resistance was similar to that of metronidazole resistance (48). However, in Japan, the occurrence of clarithromycin resistance (29\% to $41 \%$ ) exceeded that of metronidazole resistance (46), and secondary clarithromycin resistance from France and Japan was reported to be as high as $52 \%$ and $78 \%$, respectively $(35,46)$. Combined resistance to metronidazole and clarithromycin ranged from $4 \%$ to $17 \%(34-38,40-42,44,46,48,49,53)$. Only three studies of children from Italy (37), the United States (48) and Mexico (49) reported primary resistance to amoxicillin; resistance in these populations was $3 \%, 5 \%$ and $16 \%$, respectively $(37,48,49)$.

Resistance of $H$ pylori to a nitroimidazole, clarithromycin and other drugs plays a major role in treatment failure in adults (14). H pylori eradication in adults decreased by $0.5 \%$ for every $1 \%$ increase in the prevalence of metronidazole-resistant strains (14). While data were sparse for pediatric studies, treatment regimens in head-to-head studies were consistently more efficacious when the strain of $H$ pylori was sensitive to the drugs in the regimen (Figure 4). In five studies $(29,30,46,51,52)$ that reported treatment efficacy by clarithromycin resistance, $83 \%$ to $100 \%$ of clarithromycin-sensitive $H$ pylori infections, versus $0 \%$ to $56 \%$ resistant infections, were cured after treatment with PPI-CA. In Spain, 88\% of the metronidazole-sensitive strains were eradicated with BAM, compared with only $50 \%$ of the metronidazole-resistant strains (31).

\section{Reinfection}

When reported, some reinfection was observed in children, especially in the first six to 12 months after treatment. Reinfection occurred in $0 \%$ to $7 \%$ of children per month after eradication $(4,9,12,56-59)$. Lower reinfection proportions were reported when the follow-up times were longer; for example, Oderda et al (60), Huang et al (12) and Kato et al (61) reported reinfection in $0.13 \%$ to $1 \%$ per month after 18 to 28 months of follow-up. Other studies (62) have observed reinfection to be associated with treatment efficacy, family size, age, socioeconomic status, exposure to subsequent

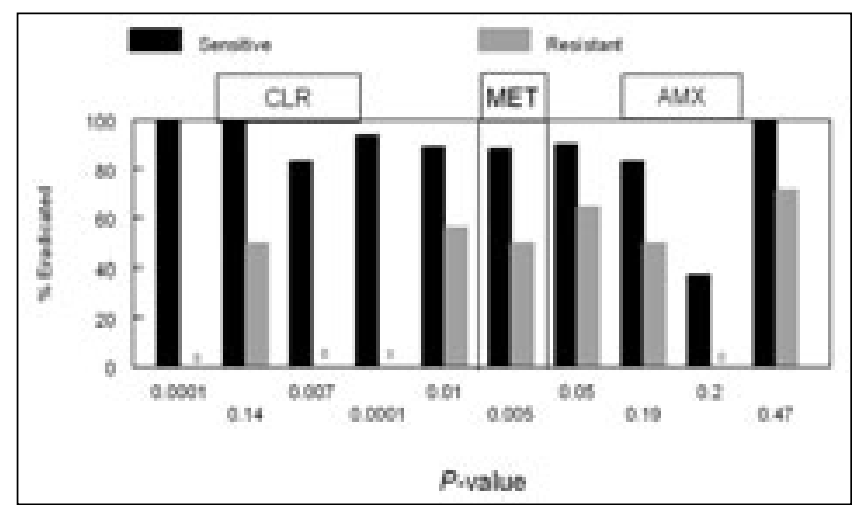

Figure 4) Proportion of Helicobacter pylori eradication in clarithromycin (CLR)-, metronidazole (MET)- and amoxicllin (AMX)sensitive and resistant strains in head-to-head studies

endoscopies and geographical location. Because treatment efficacy is a predictor of reinfection, it seems likely that a proportion of cases are due to recrudescence rather than true reinfection.

\section{Rescue therapies}

Only two studies were identified that reported eradication proportions with second-line treatment. After the initial treatment failure using amoxicillin and cimetidine or cimetidine alone, or bismuth and metronidazole in combination, only $12.5 \%$ and $41.2 \%$ of $H$ pylori infections were eradicated with rescue therapies containing a PPI with clarithromycin and a nitroimidazole for one week (63), or amoxicillin alone for two weeks (9), respectively.

\section{DISCUSSION}

The ideal therapy to eradicate $H$ pylori should be safe and effective in both the short and long term for populations requiring treatment. Studies of $H$ pylori eradication in children (6) were smaller and generally methodologically weak compared with the better designed randomized controlled trials in adults. The treatment regimens that were more than $80 \%$ efficacious in children included two-week dual therapy with AN in Europe; two-week BAM treatment in developed countries; one- to two-week PPI-CA treatment in Asia, Northern Europe and the Middle East; and two-week PPI-MacN treatment in Canada. PPI-AN, although used in only five treatment arms in France and Italy, eradicated $74 \%$ to $100 \%$ of infections; further testing may show this therapy to be effective in some populations of children.

Previous consensus statements for North American children have recommended one to two weeks of treatment with PPI-CA or PPI-CM $(5,6)$, which reflect recommendations for adults $(7,8)$. Although one- to two-week treatment with PPI-CA eradicated $84 \%$ of $H$ pylori infections in trials in Northern Europe, Asia and the Middle East, and appears to be safe and readily available in most populations of children, it eradicated less than $75 \%$ of infections in children resistant to clarithromycin, and in populations in Latin America and the United States $(20,29,30,46,64,65)$, where both metronidazole and clarithromycin resistance rates in children are high $(48,49)$. Trials using PPI-CA in Canadian children have not been reported, but in one nonrandomized trial, the efficacy of PPI-MacN was 93\% in Canada (21). In many populations outside of Canada, however, the efficacy of PPI-MacN was less than $80 \%$. Furthermore, regimens containing metronidazole 
may be less desirable for children because it is not available in liquid form and has an unpleasant taste (5). Many regimens have yet to be tested in developing countries and neither AN nor PPI-AN has been evaluated in North American children. However, the Canadian Helicobacter Study Group has endorsed this PPI-based triple therapy as an alternative therapy in adults (8).

There are some newer regimens that appear very promising in the treatment of $\mathrm{H}$ pylori in adults, which may also be effective in children. Quinolone triple therapies, when used in combination with a PPI and either amoxicillin, tinidazole or clarithromycin, have intention-to-treat eradication rates of approximately $90 \%$ in adults (66-68); however, the safety of quinolones in pediatrics has not been established. Another regimen, a one-week quadruple regimen with a PPI, amoxicillin, clarithromycin and metronidazole, eradicated $94 \%$ of $H$ pylori infections in children (23). In adults, this regimen had an efficacy of approximately $90 \%$ when given for only five days (69-72). This would be a suitable regimen for children because shorter duration may help to improve compliance.

Although only minor adverse events have been reported with anti-H pylori therapies in children, tetracycline may damage the dental enamel, and this drug should not be used in children younger than 12 years of age $(73,74)$. Thus, although the quadruple regimen of PPI, bismuth, metronidazole and tetracycline (PPI-BMT) is highly effective in adults, and has been recommended for both first-line and salvage therapy (8), it is recommended only for children older than 12 years of age. Acetylsalicylic acid and nonacetylsalicylic

\section{REFERENCES}

1. Bourke B, Jones N, Sherman P. Helicobacter pylori infection and peptic ulcer disease in children. Pediatr Infect Dis J 1996;15:1-13.

2. Bujanover Y, Reif S, Yahav J. Helicobacter pylori and peptic disease in the pediatric patient. Pediatr Clin North Am 1996;43:213-34.

3. Drumm B. Helicobacter pylori in the pediatric patient. Gastroenterol Clin North Am 1993;22:169-82.

4. Israel DM, Hassall E. Treatment and long-term follow-up of Helicobacter pylori-associated duodenal ulcer disease in children. J Pediatr 1993;123:53-8.

5. Sherman P, Hassall E, Hunt RH, Fallone CA, Veldhuyzen van Zanten S, Thompson AB. Canadian Helicobacter Study Group consensus conference on the approach to Helicobacter pylori infection in children and adolescents. Can J Gastroenterol 1999;13:553-9.

6. Gold BD, Colletti RB, Abbott M, et al; North American Society for Pediatric Gastroenterology and Nutrition. Helicobacter pylori infection in children: Recommendations for diagnosis and treatment. J Pediatr Gastroenterol Nutr 2000;31:490-7.

7. Malfertheiner P, Megraud F, O'Morain C, et al; European Helicobacter pylori Study Group. Current concepts in the management of Helicobacter pylori infection - the Maastricht 2-2000 Consensus Report. Aliment Pharmacol Ther 2002;16:167-80.

8. Hunt RH, Fallone C, Veldhuyzen van Zanten SJO, Sherman P, Smaill F, Thomson AB; Canadian Helicobacter Study Group. Risks and benefits of Helicobacter pylori eradication: Current status. Can J Gastroenterol 2002;16:57-62.

9. Yeung CK, Fu KH, Yuen KY, et al. Helicobacter pylori and associated duodenal ulcer. Arch Dis Child 1990;65:1212-6.

10. Oderda G, Caristo P, Kuvidi M, et al. Evaluation of different treatment schedules in childhood Helicobacter pylori gastritis: A 10 year experience. Gut 1999;45(Suppl 111):A94. (Abst)

11. Choe YH, Kim SK, Son BK, Lee DH, Hong YC, Pai SH. Randomized placebo controlled trial of Helicobacter pylori eradication for irondeficiency anemia in preadolescent children and adolescents. Helicobacter 1999;4:135-9.

12. Huang FC, Chang MH, Hsu HY, Lee PI, Shun CT. Long-term follow-up of duodenal ulcer in children before and after eradication of Helicobacter pylori. J Pediatr Gastroenterol Nutr 1999;28:76-80.

13. Sherman P, Shames B, Loo V, Matlow A, Drumm B, Penner J. Omeprazole therapy for Helicobacter pylori infection. Scand J Gastroenterol 1992;27:1018-22. acid salicylates, such as bismuth subsalicylate, are associated with Reye's syndrome in children with febrile illness and should be used with caution (only if the child does not have a febrile illness [75]). The two studies that measured bismuth levels with $H$ pylori therapy in children showed that levels were well below the neurotoxic range $(24,25)$.

Because there were almost no data for treatment of $\mathrm{H}$ pylori eradication failures in pediatrics, recommendations stem largely from adult data. The present recommendation for rescue therapy is to administer a second course of alternate PPI triple therapy (PPI-CM if PPI-CA was used first or vice versa) or a quadruple therapy of PPI-BMT (8). While the PPI-BMT therapy is the most robust in adults, the use of tetracycline can be problematic as already discussed. Rifabutin- and levofloxacin-based therapies appear effective in adults, but rifabutin is expensive and there are limited safety data for either drug in children (76-78). Thus, at this time, these regimens would need further study in children before recommendations for their general use can be made.

Metronidazole and clarithromycin resistance are common in developing countries, Canada and the United States, and no therapy has yet been identified as safe and consistently effective to eradicate $H$ pylori infection in children in these populations. Therefore, in addition to the need to identify safe and effective anti-H pylori rescue therapies in children throughout the world, there is also a need to identify safe and effective primary eradication therapies for $\mathrm{H}$ pylori-infected children in North America and developing countries, especially in populations where the prevalence of metronidazole and/or clarithromycin resistance is high.

14. Fischbach LA, Goodman KJ, Feldman M, Aragaki C. Sources of variation of Helicobacter pylori treatment success in adults worldwide: A meta-analysis. Int J Epidemiol 2002;31:128-39.

15. Radhakrishnan S, al Nakih B, Kalaoui M, Patric J. Helicobacter pyloriassociated gastritis in Kuwait: Endoscopy-based study in symptomatic and asymptomatic children. J Pediatr Gastroenterol Nutr 1993;16:126-9.

16. Gottrand F, Kalach N, Spyckerelle C, et al. Omeprazole combined with amoxicillin and clarithromycin in the eradication of Helicobacter pylori in children with gastritis: A prospective randomized double-blind trial. J Pediatr 2001;139:664-8.

17. Kato S, Takeyama J, Ebina K, Naganuma H. Omeprazole-based dual and triple regimens for Helicobacter pylori eradication in children. Pediatrics 1997;100:E3.

18. Behrens R, Lang T, Keller KM, et al. Dual versus triple therapy of Helicobacter pylori infection: Results of multicentre trial. Arch Dis Child 1999;81:68-70.

19. Alarcon T, Martinez MJ, Domingo D, et al. Eradication rates on dual or triple therapies including amoxicillin according to the amoxicillin MIC level in a pediatric population. Gut 1999;45:A99. (Abst)

20. Shashidhar H, Peters J, Lin CH, Rabah R, Thomas R, Tolia V. A prospective trial of lansoprazole therapy for pediatric Helicobacter pylori infection. J Pediatr Gastroenterol Nutr 2000;30:276-82.

21. Dohil R, Israel DM, Hassall E. Effective 2-wk therapy for Helicobacter pylori disease in children. Am J Gastroenterol 1997;92:244-7.

22. Carvalho AST, Queiroz DMM, Mendes EN, Rocha GA. Triple antimicrobial therapy plus $\mathrm{H}_{2}$ receptor antagonist or omeprazole in the eradication of Helicobacter pylori in children with duodenal ulcer. Gut 1998;43(Suppl 2):A74. (Abst)

23. Chan KL, Zhou H, Ng DK, Tam PK. A prospective study of a one-week nonbismuth quadruple therapy for childhood Helicobacter pylori infection. J Pediatr Surg 2001;36:1008-11.

24. De Giacomo C, Fiocca R, Villani R, et al. Helicobacter pylori infection and chronic gastritis: Clinical, serological and histological correlation in children treated with amoxicillin and colloidal bismuth subcitrate. J Pediatr Gastroenterol Nutr 1990;11:310-6.

25. Mahony MJ, Wyatt JI, Littlewood JM. Management and response to treatment of Helicobacter pylori gastritis. Arch Dis Child 1992;67:940-3.

26. McNulty CA. The treatment of Campylobacter-associated gastritis. Am J Gastroenterol 1987;82:245-7.

27. Goddard AF, Sherwood PV. Bioavailability of antimicrobials after oral 
and parenteral administration. In: Hunt RH, Tytgat GNJ, eds. Helicobacter pylori: Basic Mechanisms to Clinical Cure. Dordrecht: Kluwer Academic Publishers, 1998:392-7.

28. Kalach N, Raymond J, Benhamou PH, et al. Spiramycin as an alternative to amoxicillin treatment associated with lansoprazole/metronidazole for Helicobacter pylori infection in children. Eur J Pediatr 1998;157:607-8.

29. Kalach N, Raymond J, Benhamou PH, Bergeret M, Dupont C. Shortterm treatment with amoxycillin, clarithromycin and lansoprazole during Helicobacter pylori infection in children. Clin Microbiol Infect 1999;5:235-6.

30. Raymond J, Kalach N, Bergeret M, et al. Effect of metronidazole resistance on bacterial eradication of Helicobacter pylori in infected children. Antimicrob Agents Chemother 1998;42:1334-5.

31. Lopez-Brea M, Martinez MJ, Domingo D, Sanchez I, Alarcon T. Metronidazole resistance and virulence factors in Helicobacter pylori as markers for treatment failure in a paediatric population. FEMS Immunol Med Microbiol 1999;24:183-8.

32. Glupczynski Y, Burette A, De Koster E, et al. Metronidazole resistance in Helicobacter pylori. Lancet 1990;335:976-7.

33. Dhaenens L, Szczebara F, Husson MO. In-vitro activities of clarithromycin and other antimicrobial agents against Helicobacter pylori isolated from children. J Antimicrob Chemother 1996;38:318-9.

34. Bak-Romaniszyn L, Planeta-Malecka I, Czkwianianc E, Rozynek E, Dzierzanowska D, Laszewicz W. [Drug sensitivity of Helicobacter pylori strains in children and young people from the region of Lodz]. Med Wieku Rozwoj 2003;7:129-35.

35. Kalach N, Benhamou PH, Bergeret M, et al. [Acquisition of secondary resistance after a first course failure of treatment of Helicobacter pylori infection in children]. Arch Pediatr 2002;9:130-5.

36. Crone J, Granditsch G, Huber WD, et al. Helicobacter pylori in children and adolescents: Increase of primary clarithromycin resistance, 1997 2000. J Pediatr Gastroenterol Nutr 2003;36:368-71.

37. Street M, Caruana P, Caffarelli C, et al. Antibiotic resistance and antibiotic sensitivity based treatment in Helicobacter pylori infection: Advantages and outcome. Arch Dis Child 2001;84:419-22.

38. Rozynek E, Dzierzanowska D, Celinska-Cedro D, Jeljaszewicz J. Primary resistance to metronidazole and other antibiotics of Helicobacter pylori isolated from children in Poland. Eur J Clin Microbiol Infect Dis 1997;16:943-4.

39. Lopez-Brea M, Martinez MJ, Domingo D, Alarcon T. A 9-year study of clarithromycin and metronidazole resistance in Helicobacter pylori from Spanish children. J Antimicrob Chemother 2001;48:295-7.

40. Kalach N, Bergeret M, Benhamou PH, Dupont C, Raymond J. High levels of resistance to metronidazole and clarithromycin in Helicobacter pylori strains in children. J Clin Microbiol 2001;39:394-7.

41. Cabrita J, Oleastro M, Matos R, et al. Features and trends in Helicobacter pylori antibiotic resistance in Lisbon area, Portugal (19901999). J Antimicrob Chem 2000;46:1029-31.

42. Bontems P, Devaster J, Corvaglia L, et al. Twelve year observation of primary and secondary antibiotic-resistant Helicobacter pylori strains in children. Pediatr Infect Dis J 2001;20:1033-8.

43. Mentis AF, Roma E, Pangalis A, Katsiyiannakis E. Susceptibilities of Helicobacter pylori strains isolated from children with gastritis to selected antibiotics. J Antimicrob Chemother 1999;44:720-2.

44. Rerksuppaphol S, Hardikar W, Midolo PD, Ward P. Antimicrobial resistance in Helicobacter pylori isolates from children. J Paediatr Child Health 2003;39:332-5.

45. Fujimura S, Kato S, Kawamura T, Watanabe A. In vitro activity of rifampin against Helicobacter pylori isolated from children and adults. J Antimicrob Chemother 2002;49:541-3.

46. Kato S, Fujimura S, Udagawa H, et al. Antibiotic resistance of Helicobacter pylori strains in Japanese children. J Clin Microbiol 2002;40:649-53.

47. Yang YJ, Yang JC, Jeng YM, Chang MH, Ni YH. Prevalence and rapid identification of clarithromycin-resistant Helicobacter pylori isolates in children. Pediatr Infec Dis J 2001;20:662-6.

48. Tolia V, Brown W, El-Baba M, Lin CH. Helicobacter pylori culture and antimicrobial susceptibilities from pediatric patients in Michigan. Pediatr Infect Dis J 2000;19:1167-71.

49. Torres J, Camorlinga-Ponce M, Perez-Perez G, et al. Increasing multidrug resistance in Helicobacter pylori strains isolated from children and adults in Mexico. J Clin Microbiol 2001;39:2677-80.

50. Domingo D, Alarcon T, Vega AE, Garcia JA, Martinez MJ, Lopez-Brea M. [Microbiological factors that influence the eradication of Helicobacter pylori in adults and children]. Enferm Infecc Microbiol Clin 2002;20:431-4.

51. Jesch I, Kindermann A, Krauss-Etschmann S, et al. Prevalence of clarithromycin-resistant $H$. pylori strains in children: Effect on therapy. Gut 1999;45:A93. (Abst)

52. Kalach N, Benhamou PH, Campeotto F, Bergeret M, Dupont C, Raymond J. Clarithromycin resistance and eradication of Helicobacter pylori in children. Antimicrob Agents Chemother 2001;45:2134-5.
53. Kalach N, Benhamou PH, Dupout C, et al. Helicobacter pylori in children: Acquisition of antimicrobial resistance after an initial course of treatment. J Clin Microbiol 2001;39:3018-9.

54. Feydt-Schmidt A, Russmann H, Lehn N, et al. Fluorescence in situ hybridization vs epsilometer test for detection of clarithromycinsusceptible and clarithromycin-resistant Helicobacter pylori strains in gastric biopsies from children. Aliment Pharmacol Ther 2002;16:2073-9.

55. Dzierzanowska-Fangrat K, Rozynek E, Jozwiak P, Celinska-Cedro D, Madalinski K, Dzierzanowska D. Primary resistance to clarithromycin in clinical strains of Helicobacter pylori isolated from children in Poland. Int J Antimicrob Agents 2001;18:387-90.

56. Cucchiara S, Salvia G, Az-Zeqeh N, et al. Helicobacter pylori gastritis and non-ulcer dyspepsia in childhood. Efficacy of one-week triple antimicrobial therapy in eradicating the organism. Ital J Gastroenterol 1996;28:430-5

57. Cilleruelo ML, Urruzuno P, Martinez NJ, et al. Helicobacter pylori reinfection after eradication in children. Gut 1997;41:A70. (Abst)

58. Martinez MJ, Sanz JC, Garcia N, et al. Reinfection after Helicobacter pylori eradication in pediatric patients. Gut 1999;45:A96. (Abst)

59. Walsh D, Goggin N, Rowland M, Durnin M, Moriarty S, Drumm B. One week treatment for Helicobacter pylori infection. Arch Dis Child 1997;76:352-5.

60. Oderda G, Vaira D, Ainley C, et al. Eighteen month follow up of Helicobacter pylori positive children treated with amoxicillin and tinidazole. Gut 1992;33:1328-30.

61. Kato S, Abukawa D, Furuyama N, Iinuma K. Helicobacter pylori reinfection rates in children after eradication therapy. J Pediatr Gastroenterol Nutr 1998;27:543-6.

62. Xia HX, Talley NJ, Keane CT, O'Morain CA. Recurrence of Helicobacter pylori after successful eradication: Nature and possible causes. Dig Dis Sci 1997;42:1821-34.

63. Moshkowitz M, Reif S, Brill S, et al. One-week triple therapy with omeprazole, clarithromycin, and nitroimidazole for Helicobacter pylori infection in children and adolescents. Pediatrics 1998;102:E14.

64. Kawakami E, Ogata SK, Portorreal AC, Magni AM, Pardo ML, Patricio FR. Triple therapy with clarithromycin, amoxicillin and omeprazole for Helicobacter pylori eradication in children and adolescents. Arq Gastroenterol 2001;38:203-6.

65. Yanez P, la Garza AM, Perez-Perez G, Cabrera L, Munoz O, Torres J Comparison of invasive and noninvasive methods for the diagnosis and evaluation of eradication of Helicobacter pylori infection in children. Arch Med Res 2000;31:415-21.

66. Cammarota G, Cianci R, Cannizzaro O, et al. Efficacy to two one-week rabreprazole/levofloxacin-based triple therapies for Helicobacter pylori infection. Aliment Pharamacol Ther 2000;14:1339-43.

67. Di Caro S, Assunta Zocco M, Cremonini F, et al. Levofloxacin based regimens for the eradication of Helicobacter pylori. Eur J Gastroenterol Hepatol 2002;14:1309-12.

68. Di Caro S, Ojetti V, Zocco MA, et al. Mono, dual and triple moxifloxacin-based therapies for Helicobacter pylori eradication. Aliment Pharmacol Ther 2002;16:527-32.

69. Nagahara A, Miwa H, Yamada T, Kurosawa A, Ohkura R, Sato N. Five-day proton pump inhibitor-based quadruple therapy regimen is more effective than 7-day triple therapy regimen for Helicobacter pylori infection. Aliment Pharmacol Ther 2001;15:417-21.

70. Nagahara A, Miwa H, Ogawa K, et al. Addition of metronidazole to rabeprazole-amoxicillin-clarithromycin regimen for Helicobacter pylori infection provides an excellent cure rate with five-day therapy. Helicobacter 2000;5:88-93.

71. Treiber G, Ammon S, Schneider E, Klotz U. Amoxicillin/metronidazole/omeprazole/clarithromycin: A new, short quadruple therapy for Helicobacter pylori eradication. Helicobacter 1998;3:54-8.

72. Neville PM, Everett S, Langworthy $\mathrm{H}$, et al. The optimal antibiotic combination in a 5-day Helicobacter pylori eradication regimen. Aliment Pharmacol Ther 1999;13:497-501.

73. Smith DM, Straffon LH. Dental staining due to tetracycline administration. Mich Med 1967;66:464-6.

74. Scopp IW, Kazandjian G. Tetracycline-induced staining of teeth. Postgrad Med 1986;79:202-3.

75. Clark I, Whitten R, Molyneux M, Taylor T. Salicylates, nitric oxide, malaria, and Reye's syndrome. Lancet 2001;357:625-7.

76. Perri F, Festa V, Clemente R, et al. Randomized study of two "rescue" therapies for Helicobacter pylori-infected patients after failure of standard triple therapies. Am J Gastroenterol 2001;96:58-62.

77. Wong WM, Gu Q, Lam SK, et al. Randomized controlled study of rabeprazole, levofloxacin and rifabutin triple therapy vs quadruple therapy as second-line treatment for Helicobacter pylori infection. Aliment Pharmacol Ther 2003;17:553-60.

78. Nista EC, Candelli M, Cremonini F, et al. Levofloxacin-based triple therapy vs quadruple therapy in second-line Helicobacter pylori treatment: A randomized trial. Aliment Pharmacol Ther 2003;18:627-33. 


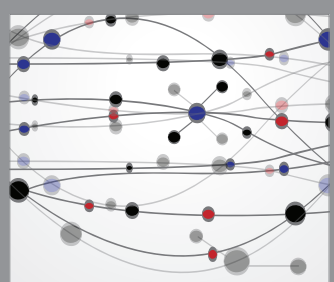

The Scientific World Journal
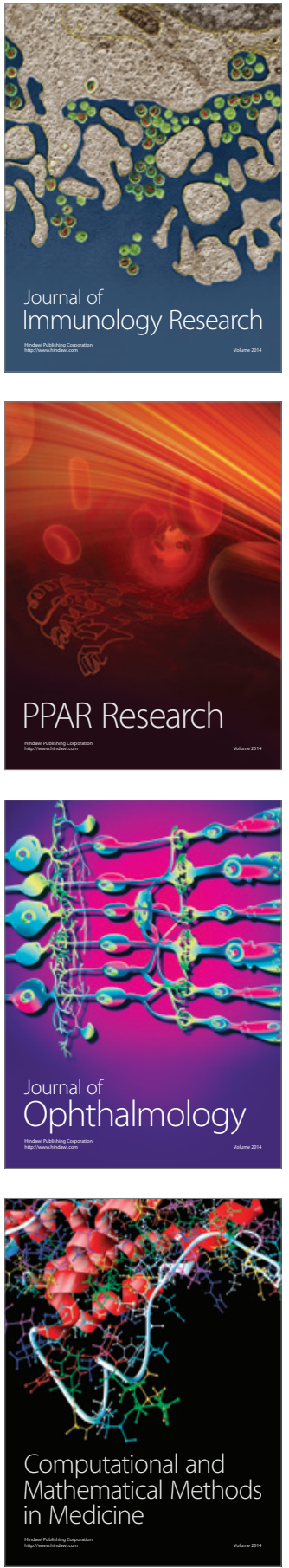

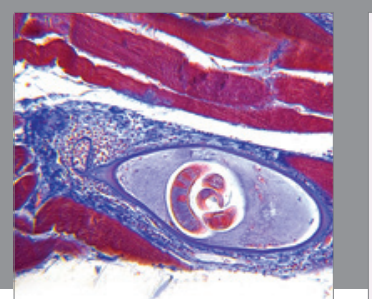

Gastroenterology Research and Practice

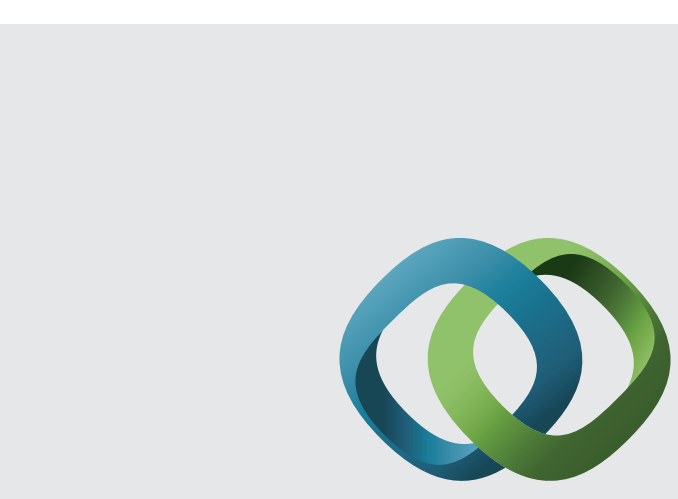

\section{Hindawi}

Submit your manuscripts at

http://www.hindawi.com
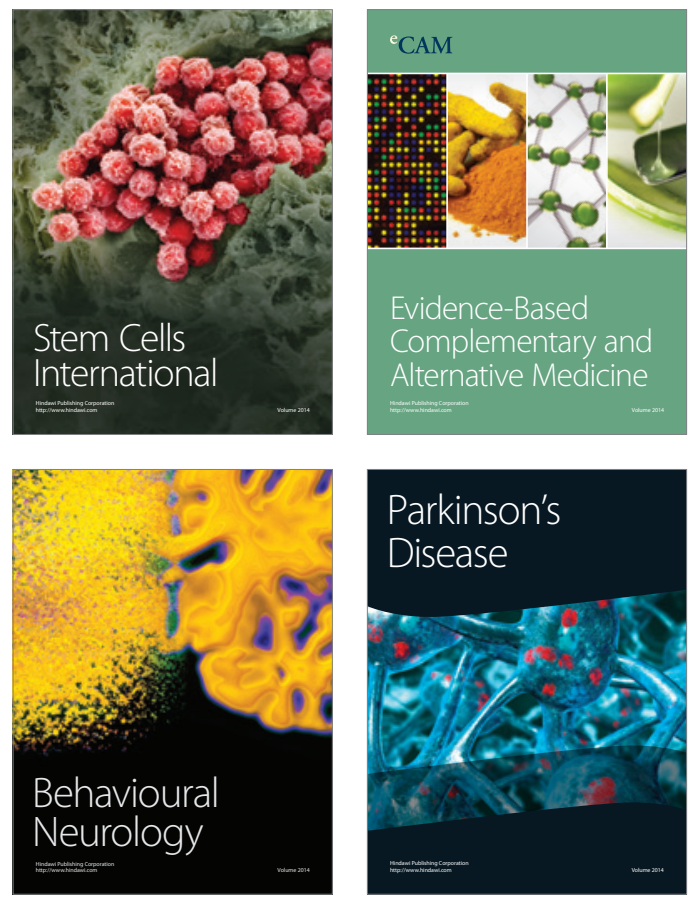
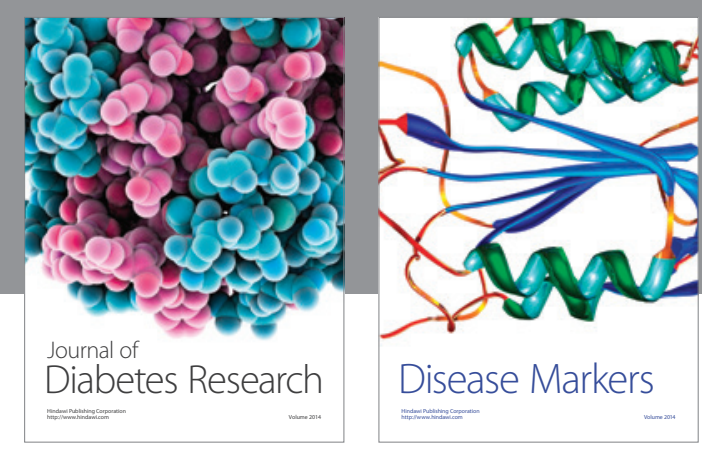

Disease Markers
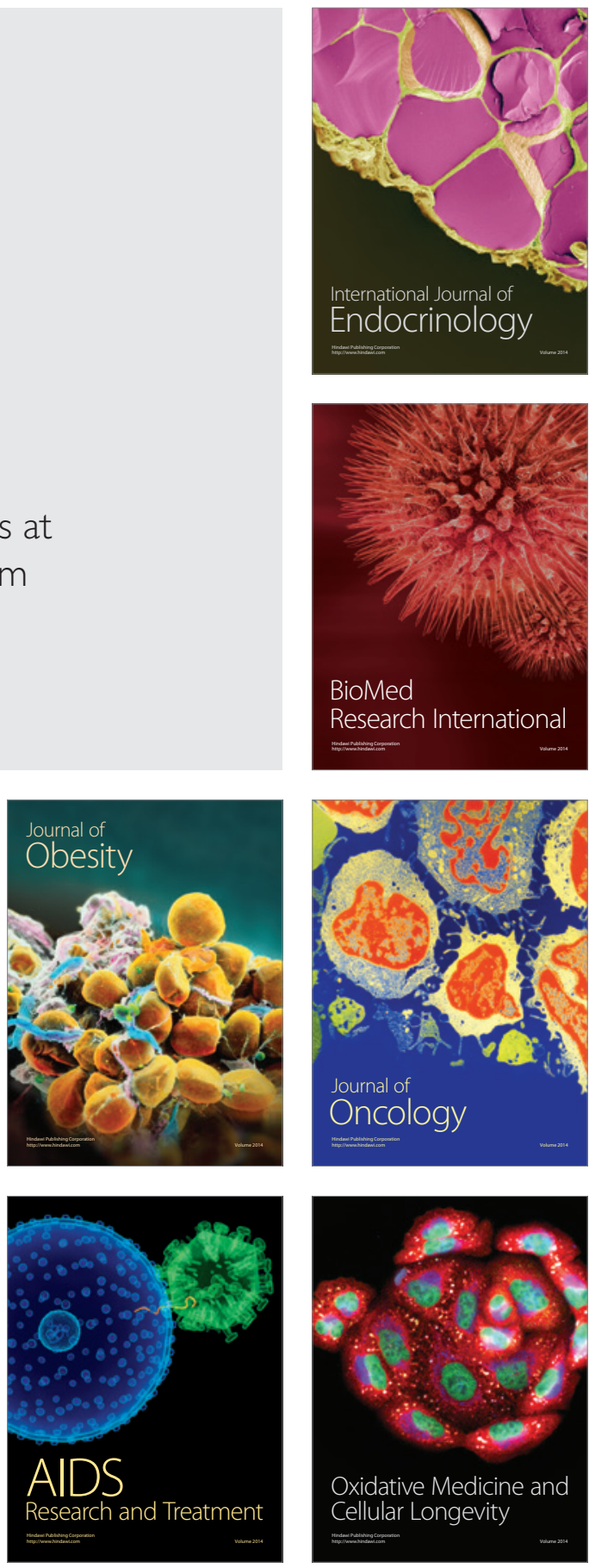